\title{
PEDAGOGY AND PRAXIS: POSTMODERN SPIRIT IN THE CLASSROOM
}

\author{
DAVID NYLUND, PH.D., M.S.W. \\ California State University-Sacramento \\ JULIE TILSEN, M.A. \\ Argosy University-Twin Cities
}

\begin{abstract}
This article identifies some of the benefits of using a postmodern approach in a social work practice or family therapy classroom. A postmodern pedagogical stance has particular significance for faculty who teach clinical practice as postmodernism encourages reflexivity and increases students' awareness of sociopolitical issues. We provide an overview of critical pedagogy and its relationship to postmodern theory. Specific ideas for classroom activities and assignments that enhance students' critical thinking along with ideas for student evaluation are illustrated that add to the learning process and flatten the hierarchy between student and teacher.
\end{abstract}

You know the courses. We all do-the broad brush-stroke, around-the-therapyworld in 45 credit hours, overview of all the "major" schools of psychotherapy. Invariably, the textbooks we use reveal their biases and their blind spots. You know that no matter how much effort you put into giving equal time to each school you will be accused of favoring those "new" therapies. No matter what angle you take, frustration wraps its steely fingers around you and nary a unique outcome is in sight as you sigh at the futility of it all.

This article discusses the ways postmodernism has shaped our educational philosophies and classroom experiences in the pedagogy of therapeutic practices. David is a professor of social work at California State University, Sacramento, and Julie is an adjunct faculty in the marriage and family therapy program at Argosy UniversityTwin Cities. Some of the questions we tackle include: What implications does postmodernism have for teaching about therapeutic work? What is the relationship between student and teacher? How do we teach assessment and models of practice without duplicating modernist ideas of norms and "truths?" How do we

Address correspondence to David Nylund, 6000 J. St., Sacramento, CA 95819; dknylund@ @sus.edu. 
evaluate student progress in a collaborative, postmodern manner? This article identifies some of the advantages of using a postmodern approach in a psychotherapy or family therapy classroom (Julie teaches in a MFT program while David teaches in social work). We will begin our discussion with an overview of the underlying assumptions that inform our engaged pedagogy and then illuminate some of the specific postmodern pedagogical practices we use in our classrooms.

\section{POSTMODERNISM: IS IT JUST RELATIVIST AND FANCY VOCABULARY?}

In recent years the subject of postmodernism has sparked numerous debates in and outside the academy. Part of the reason for these debates is that a postmodern epistemology requires a paradigm shift, and in the field of family therapy this shift is a radical one. Most psychotherapies remain entrenched in a modernist paradigm (Smith, 1997). A modernist paradigm is characterized by the belief that truths about human behavior can be found and adherence to the methods of the natural sciences is the best path by which to discover them (Best \& Kellner, 1991). Postmodernism, by virtue of its rejection of the idea that it is possible to characterize reality objectively or accurately, engenders concerns about relativism or even nihilism. Some academics and therapists worry that incorporating a postmodern epistemology will undermine the status of psychotherapy as a scientific discipline in an era when evidence-based practice models are in vogue. Locke (2002) expressed this fear strongly: "like anthrax of the intellect, if allowed into mainstream psychology, postmodernism will poison the field" (p. 458). In other words, how can students learn about the science of human behavior or the science of psychopathology if teachers adopt a paradigm that challenges the very notion of achieving scientific truths about human experience? As Gergen (2001) noted, however, "if psychologists [therapists] can replace a defensive posture with more productive participation in postmodern dialogues, psychological inquiry can be transformed in ways that will deeply enrich our endeavors" (p. 803). Following Gergen (2001), we argue that utilizing a postmodern approach helps students develop critical thinking skills, strengthens students' awareness of social justice issues, and encourages activism within the field.

\section{ON THE SHOULDERS OF PAULO FREIRE}

Our pedagogical style has been significantly influenced by critical educator Paulo Freire (1999). Freire focuses on the development of critical consciousness, which enables learners to recognize connections between their individual problems and experiences and the social contexts in which they are embedded. Coming to consciousness is the necessary first step of "praxis," configured as an ongoing, reflective approach to taking action. Praxis involves engaging in a cycle of theory, 
application, appraisal, and reflection. Freire believes that social revolution is the result of praxis at the communal level.

According to Freire in Pedagogy of the Oppressed (1999), education is traditionally framed as "an act of depositing, in which the students are the depositories and the teacher is the depositor" (p. 53). In this framework, the teacher lectures, and the students memorize and repeat. Freire explains that this "banking" model of education is generally characterized by the following oppressive attitudes and practices: the teacher teaches and the students are taught; the teacher knows everything and the students know nothing; the teacher thinks and the students are thought about; the teacher talks and the students listen-meekly; the teacher confuses the authority of knowledge with his own professional authority, which he sets in opposition to the freedom of the students; and the teacher is the subject of the learning process, while the pupils are mere objects. The dialogical approach to learning abandons the lecture format and the banking approach to education in favor of dialogue and open communication among students and teachers. According to Freire, in this method teaching and learning are a two-way process. The dialogical method contrasts with the antidialogical method, which positions the teacher as the transmitter of knowledge, a hierarchical framework that leads to marginalization through the silencing of students' knowledge and experiences.

Freire's dialogical method has enabled us to situate our role as teachers as "participant managers" (Allen, 1993, p. 38) of the classroom conversation. We view it as our responsibility to keep the discussion moving along by drawing upon the unique knowledges and diversity of the class members for multiple perspectives. We may ask students to deliberately take up alternative views and defend them, particularly marginal viewpoints.

Postmodern, feminist, antiracist, postcolonial, and queer theories have all played a role in expanding our notion of Freirean critical pedagogy, shifting his predominant focus on class to include categories such as race, gender, sexuality, ethnicity, nationality, and age. In place of the modernism upon which Freire's vision of liberatory education relies, we have adopted more poststructuralist, antiessentialist conceptions of identity, language, and power, while at the same time retaining the Freirean emphasis on challenging oppressive regimes of power and social change. This has led us to focus on the sociopolitical context of many of the conventional family and social work theories. For instance, we ask our students such questions as, What are the gendered assumptions about what constitutes a healthy family according to Bowen? What does this theory say about sexuality, race, and other issues? Why are the majority of youth who are labeled "conduct disorder" African American males?

To assist us in interrogating issues of race, class, gender, and sexuality in family therapy and social work, we have turned to critical educators who have been influenced by postmodernism, such as Giroux (1983), hooks (1994), and McLaren (1989). These educators have reworked some of Freire's ideas utilizing a postmodernist framework. Much of their work analyzes the impact of various issues, institutions, 
and social structures, including globalization, the mass media, and race relations, while also pointing out potentially productive sites of resistance and possibilities for social change. Their ideas have inspired us to bring issues of social justice and larger social context to the forefront of our clinical discussions in class.

In particular, our teaching philosophy has been significantly influenced by Giroux (1983), who has appropriated some postmodern theoretical concepts but has not abandoned modernist categories altogether, calling for a reconstruction of modern categories such as democracy, identity, liberation, and social justice. His work is appealing to us because it critiques modernism and suggests new alternatives that draw upon modern and postmodern insights. Rather than ignoring difference, as modernist theory tended to do, or valorizing the endless play of difference (and ignoring power), which is characteristic of some postmodernist theory, Giroux affirms difference while simultaneously defending the necessity of finding ways to articulate shared goals and values. Giroux points to the play of identity and difference as opening up possibilities for new and more collaborative forms of discourses and practices. As Giroux points out, postmodernism can be viewed as giving teachers a new set of theoretical tools for addressing important questions about how narratives get constructed, what they mean, how they regulate particular forms of moral and social experience, and how they presuppose and embody particular epistemologies and views of the world. His ideas are very useful in deconstructing many of the discourses and taken-for-granted assumptions in family therapy and social work, for instance, the idea of what constitutes a healthy heterosexual marriage.

Giroux has also helped us to realize that we as postmodern educators cannot assume that the development of a critical awareness will lead our students to see reality in a predefined, standardized way. Many students, even with exposure to postmodern ideas, may still find modernist theories such as structural family therapy or object relations theory useful. As postmodern critical educators, we expect that our diverse students will have radically different responses to class discussions that they cannot anticipate in advance. We do not view lack of classroom consensus or student unwillingness to adopt postmodern positions as a failure of our students or ourselves. Rather, we view these moments as productive spaces that allow for difference and dialogue.

\section{UNPACKING MODERNISM}

One of the ironies of teaching about postmodernism is that the main part of that term, "modernism," often goes undefined. Critical multiculturalism taught us that saying "nonwhite" or "nonheterosexual" only reifies the hegemonic norm by maintaining its position at the center of the referential universe. This is what happens when we spend all our time on postmodernism, making sense of it only as nonmodernist. We have learned that hegemonic reference points often need some interrogation themselves, lest we continue to reinforce their dominance by having them go unexamined. 
The first step in our approach to teaching postmodern therapies is to begin by shining a bright light on what constitutes modernism. This process is part deconstruction, part education (not that deconstruction is not educative). We begin the deconstruction process by asking students to consider what they know. Much of the teaching of postmodern therapy is the unteaching of modernist thinking. While we need to provide instruction in the thinking and doing of Bowenian, experiential, structural, and strategic therapies, for example, we do not have to exert the same effort in laying the foundation for those concepts and practices, because our students come to us fully immersed in the metanarratives of modernist, positivist thought. Yet, they do not know that they are immersed in modernist, positivist thought. Thus the hegemony of modernism and thus the need for deconstruction and interrogation. Some of the questions we may ask include:

- How do you know what you know?

- Who are some of the people that influenced that knowledge?

- Describe the historical and cultural circumstances that this knowledge emerged from. How do these circumstances have a bearing on the politics of this knowledge?

- If you are not familiar with these circumstances, why do you suppose that is? What are you curious about?

- In what ways has this knowledge been used that has been helpful or harmful to people? Would you say that this is equal opportunity knowledge or that it has a particular agenda?

- Would you say that this knowledge has any limitations?

- What kinds of knowledge have you found yourself more inclined to accept and what kinds have you been inclined to question?

- What have been the results of your acceptance or rejection of particular knowledges?

These questions and the discussions they generate provide an effective means for students to begin considering that "knowledge"-what they know, facts, information-is not apolitical, acontextual, ahistorical, indisputable, or benign material. As aspiring social workers and family therapists, students have already been primed for the importance of taking a good history and seeking multiple perspectives. Of course, the notion that their ideological footing may be less than solid or not quite pure of purpose can be a bit unsettling for some. This, we assert, is where learning can take place: when one can enter a space of uncertainty where previously certain and can begin to consider something new.

\section{LOCATION, LOCATION, LOCATION}

The spirit of postmodernism in the classroom is achieved in ways that parallel those of the consulting room. Consistent with the clinical practice of eschewing 
universal models and techniques, our classroom performance as instructors depends on how we position ourselves. A willingness to situate ourselves within our own social location, locate the ideas we present within their philosophical paradigms, and invite our students to situate themselves and their ideas is required in order to nurture the postmodern spirit. We value students' knowledge as much as other knowledge. Still, we have to help them situate that knowledge so that they may be able to think critically about it. It has been standard practice for family therapists to engage in "self-of-the-therapist" work. We view this critical situating as an extension of self-of-the-therapist work. In addition to asking students to consider the impact of their family of origin on their ideas and responses, we invite them to interrogate a multiplicity of contexts as possible influences. In a sense, we practice externalization (White \& Epston, 1990) by inviting a separation of the student from their knowledge. This allows them to consider their relationship with the knowledge they have.

The other crucial dimension to this positioning of ourselves is our readiness to be touched and transformed by the teaching and learning process and to be open about our mistakes, doubts, and uncertainties. In Teaching to Transgress, author, activist, and English professor hooks (1994) advocates a practice of "engaged pedagogy" in which students and teachers are empowered. Empowerment, hooks argues, cannot happen if we refuse to take risks. Professors who expect students to share confessional narratives but who are themselves unwilling to share are exercising power in a manner that could be coercive: "when professors bring narratives of their experiences into classroom discussions it eliminates the possibility that we can function as all-knowing, silent interrogators. [Empowerment] is often produced if professors take the first risk, linking confessional narratives to academic discussions so as to show how experience can illuminate and enhance our understanding of academic material" (1994, p. 21).

In classes where students will be doing role plays as clients and therapists, we play clients and therapists. If we instruct them to videotape their work and show it in class, we show our tapes. We discuss our "stuck places," the times we have said or done things we would rather not have said or done. In short, we take the same risks we ask them to take.

\section{CRITIQUING THEORY}

Once we review some of the basic tenets of modern and postmodern theory and identify our own social location, we begin a critical discussion of the various clinical theories. We suggest to our students that being aware of the philosophical assumptions of their clinical theories and practices is a core feature of ethical work. Theories, although implicit, are powerful determinants of practices that have real effects on clients. We invite our students to consider theories as metaphors, with different theories providing more or less helpful ways of viewing practice. We 
emphasize the notion of preserving those aspects of theories that are useful as a focus on the value of multiple perspectives.

To analyze and critique the various theories and to place them in their historical context, we find the following questions useful:

- What contextual forces does this theory address (individual, family, community, political, cultural)?

- How congruent is this theory with the values and ethics of social work or MFT practice?

- Does this theory support particular values or assumptions about human behavior, human nature, and how the world should be?

- At what particular point in time is this theory historically situated? When did it develop? What does this historical position suggest about the theory?

- Does this theory contribute to preserving and restoring human dignity?

- What truth claims support this theory? What is the power of this theory to define, explain, and interpret reality?

- Does this theory recognize human diversity?

- Does this theory assist us in transforming our society and ourselves?

(Adapted from Finn \& Jacobson, Just Practice, Eddie Bowers Publishing, 2003, pp. 153-154).

These questions invite students to see that all theories are socially constructed and operate from a particular positionality. Through these questions, students begin to recognize that some theories can empower clients while others can be client blaming.

\section{Illustration: A Critique of Attachment Theory}

Bowlby's (1983) attachment theory is extremely popular at this time and many of my (David's) students find the ideas useful, particularly students in child welfare placements. I am also required to teach attachment theory in my department because it is considered an "evidence-based practice model." Hence, I assign many articles that build upon Bowlby's ideas which many students enjoy reading and find beneficial in their practice. I invite critique by asking questions such as: How does attachment theory increase your understanding of your client or family? Is this theory pertinent to your client's cultural background and class status? How does this theory open space for possibility and change? What is there about our current social arrangement that produces families that so frequently fail to provide the attachment needs that children require? Such questions move the idea of attachment from an individualist frame toward a more sociopolitical context (which is a core value in social work practice and education). I also assign Franzblau's (2002) critique of attachment theory, Deconstructing Attachment Theory: Naturalizing the Politics of Motherhood. In this article, Franzblau argues that attachment 
theory is a coercive construct that legitimizes and naturalizes the control of women and contributes to divisions among women by social class, race, and sexual orientation. Assigning readings that valorize and critique attachment theory leads to a rich classroom dialogue with students taking up various perspectives. Since social context and justice are key in our version of postmodern pedagogy, articles from various stances on attachment theory help to situate the politics of gender inherent in this and many psychological and therapeutic theories.

\section{Illustration: Critiquing Systems Theory}

Another example of examining theoretical constructs from a critical and sociopolitical perspective follows. In the MFT classroom, I (Julie) follow up students' study of systems theory with the longstanding mobile activity. Students create mobiles to represent systems concepts such as feedback loops and reciprocity. However, I provide different materials to each work group. Some get the basics: sticks, string, and a few stones to represent people. Other groups get plenty of the above plus glitter, markers, feathers, and stickers of popular cartoon and media images, while a few other students receive barely enough to put a mobile together. The students' subsequent critique of the values and limitations of systems theory as a metanarrative is quite impressive as they consider the impact of unearned privilege, unequal access to resources, and unique meanings that can be made about families when considered in context.

\section{POSTMODERN PEDAGOGY AND STUDENT EVALUATION: DO WE HAVE TO GRADE?}

One of our foremost challenges we face as postmodern educators is evaluating student progress. Although we eschew normative criteria, we both work in modernist institutions that privilege teacher-directed, top-down, standardized, universal learning outcomes that prescribe the same for all students, regardless of their social location or other specific contexts. A brief explication of some of these practices suggests that there are alternative ways of approaching assessment and that educators do not need to be constrained by individual, institutional, regulatory, or societal barriers.

Grading and evaluation are the source of significant anxiety for many students. In my (Julie's) class, I encourage students to trace the history of this anxiety and its impact on their ability to learn or to experiment with a variety of practice techniques. By asking questions such as: When have you had a learning experience in which you felt free from the pressures of anxiety? What contributions did you make to that freedom from anxiety? What part did your classmates play? Your instructor? The institution? I position myself in collaboration with students and make explicit my desire to temper the impact of normative criteria. I do not hesi- 
tate to ask them what I can do to help them reach their learning goals. Further, we compare students' experiences with instructor or institutional evaluatory power with clients' experiences of therapist authority and the power to assess and diagnose. This consideration invites students to reflect on ways they may create relationships with their clients that make the power differential inherent in the therapy relationship transparent and open for renegotiation.

A postmodern pedagogy of assessment involves collaborative interactions so that the roles of teacher and learner are shared and all voices are validated. This is not to imply that we as teachers do not have some expertise in evaluating student progress. We open up space, however, for students to have ownership and power in the generation of assessment criteria. By encouraging student-generated criteria, students are more likely to implement these practices in their fieldwork. Students have also been able to identify which criteria are most relevant to their own work and contexts.

Invoking the voices of clients, for example, is one way I (Julie) invite evaluatory data that sit outside traditional normative criteria while also speaking directly to clinical effectiveness. Utilizing an "Internalized Other" (Epston, 1993; Nylund \& Corsiglia, 1998) format, we ask questions such as: How would your clients describe their relationships with you? What would they say are some of your greatest talents as a therapist? In what ways would they say you have helped them the most? What advice would your clients give you to help you continue to develop as a therapist? From their perspective, in what areas have you made the greatest progress? In addition to providing grist for the grading mill, this practice also supports our commitment to bring client voices to the center of clinical practice.

Latterly, this student generation of assessment criteria has been extended to other assessments including the traditional essays, projects, and case discussions. The tasks for assessment are identified and the students are collectively very capable of generating criteria that effectively assess the task. In our experience, the students generate criteria that are relevant and useful and have the added advantage of being owned by the students.

To further equalize the power relations between students and myself (David) and to encourage autonomy and ownership of their learning and work, I encourage students to engage in peer review and self-assessment in their assignments. For example, in their essays, I have students pair up to critique their rough drafts of their papers. In addition, during case discussion and role plays, I encourage classmates to assess each other according to student-generated assessment criteria. Peer review requires careful handling and there are barriers to overcome, including being observed and evaluated by their cohorts. Yet, by setting up a supportive context based on community and partnership, students are now using self-assessment to contribute to their summative assessments. In addition, they are becoming familiar and increasingly comfortable with reviewing the work of peers, providing feedback, and responding to feedback from colleagues on their own work.

Since a grade is required and is often a measurement of student success, we offer learning options that can enhance a particular student's learning goals. 
Students are given many alternatives: learning alone or in group, live or online, and through visual, auditory, and kinesthetic channels. Since we have embraced postmodern ideas, the options have become limitless (study groups, web-based learning, message boards, videotapes, and attending our office hours, for example) and affected only by the creativity of us and our students and the technology available. We have found that once we have been freed from the banking model of education, new worlds are opened and student learning flourishes.

Lastly, we consider evaluation to be a two-way street. In addition to the institutional midterm and end-term course evaluations, we seek student feedback on a class-by-class basis. This may be as simple as asking how they would like to use class time (viewing a film, doing an activity, working in small groups, etc.) to asking them to evaluate the use of class time and our performance as classroom managers and facilitators. We make efforts to incorporate student suggestions from both informal and formal course evaluations into our teaching.

\section{CHOICES FOR POSTMODERN EDUCATORS}

Incorporating a postmodern spirit in our classrooms requires students and faculty to engage in critical inquiry and reflection and to evaluate the theories and assumptions that inform the discipline of family therapy and psychotherapy. If we as teachers do not encourage critical thinking, students' views of therapeutic progress may become ethnocentric and decontextualized. Unfortunately, because many theories rely on intra-individual factors to explain distress, they may inadvertently sustain an unjust status quo. Teachers can help students disturb the status quo, however, by encouraging them to take up multiple perspectives and become agents of social change. In this way, postmodernism can be seen as a resource which encourages knowledge and knowledge-making. Indeed, when teachers and students alike question taken-for-granted assumptions, transcend binaries (healthy/unhealthy, normal/abnormal), and try to envision new ways of thinking, teaching truly becomes "a site of resistance" (hooks, 1994, p. 21).

In regard to student grades, we have illuminated here some of the challenges inherent in institutional contexts that privilege objectivity. To a certain extent, assessment tasks established in therapist graduate programs will never be able to avoid institutional and regulatory constraints. Yet, we believe that we, and other postmodernists, must be at the forefront of promoting assessment reconstruction alongside pedagogical reconstruction to achieve the goals of critical pedagogy and praxis. We cannot claim that our processes are entirely consistent with these goals. In fact, we know we are only in our infancy in terms of what needs to be achieved. We are completely aware of the difficulties of achieving critical pedagogy in therapist education. Though we work within the same institutional constraints experienced by most educators, however, our goal is to envision the possible, not just be controlled by the current modernist ethos. 
We have choices as postmodern educators. We can continue to do what we have always done or we can commit to change. We do not suggest that the strategies suggested here should be universally implemented. That would be inconsistent with the whole notion of postmodern pedagogy. But we do challenge others to address the issues raised here and to look at the particularities of their own contexts. Our intention is to generate a dialogic approach to assessment in therapist training, to authenticate student perspectives, to insert assessment in meaningful curricula and contexts, and to promote critical reflection and action. In such an environment, students will be better placed to examine their own contexts and behaviors and to develop their own critical pedagogy and commitment to social justice.

\section{REFERENCES}

Allen, J. (1993). The constructivist paradigm: Values and ethics. In J. Laird (Ed.), Revisioning social work education: A social constructionist approach (pp. 31-54). New York: Haworth Press.

Best, S., \& Kellner, D. (1991). Postmodern theory: Critical interrogations. New York: Guilford Press.

Bowlby, J. (1983, 2nd Ed). Attachment. New York: Basic Books.

Epston, D. (1993). Internalized other questioning with couples: The New Zealand version. In S. Gillian \& R. Price (Eds.), Therapeutic conversations (pp. 183-189). New York: Norton.

Finn, J. L., \& Jacobson, M. (2003). Just practice: A social justice approach to social work. Peosta, IA: Eddie Bowers Publishing.

Franzblau, S. H. (2002). Deconstructing attachment theory: Naturalizing the politics of motherhood. In L. H. Collins, M. R. Dunlap, \& J. C. Chrisler (Eds.), Charting a new course for feminist psychology (pp. 93-104). Westport, CT: Praeger.

Freire, P. (1999, 3rd Ed). Pedagogy of the oppressed. New York: Continuum.

Gergen, K. J. (2001). Psychological science in a postmodern world. American Psychologist, 56, 803-813.

Giroux, H. (1983). Theory and resistance in education: A pedagogy for the opposition. Boston: Bergin \& Garvey.

hooks, b. (1994). Teaching to transgress: Education as the practice offreedom. New York: Routledge.

Locke, E. A. (2002). The dead end of postmodernism. American Psychologist, 57, 458.

McLaren, P. (1989). Life in schools. White Plains, NY: Longman.

Nylund, D., \& Corsiglia, V. (1998). Internalized other questioning with men who are violent. In M. Hoyt (Ed.), Handbook of constructive therapies: Innovative approaches with leading practitioners (pp. 401-413). San Francisco, CA: Jossey-Bass.

Smith, C. (1997). Introduction: Comparing traditional therapies with narrative approaches. In C. Smith \& D. Nylund (Eds.), Narrative therapies with children and adolescents (pp. 1-52). New York: Guilford Press.

White, M., \& Epston, D. (1990). Narrative means to therapeutic ends. New York: Norton. 